\title{
Influence of anticardiolipin antibodies on immediate patient outcome after myocardial infarction
}

\author{
C Raghavan, J Ditchfield, R J Taylor, M R Haeney, P C Barnes
}

\begin{abstract}
Aims-To determine whether the presence of anticardiolipin antibodies in patients with suspected myocardial infarction is predictive of complications during hospital stay or after discharge. Methods-Anticardiolipin antibodies were serially measured in a cohort of 111 patients, from the time of admission to the coronary care unit till eight weeks after discharge. Associations with fatal and non-fatal cardiac complications were documented.

Results-The incidence of raised titres of IgG and IgM anticardiolipin antibodies (ACA) in patients with myocardial infarction was comparable with that in patients with ischaemic heart disease. ACA titres in patients with a previous myocardial infarct were not significantly different from those found in patients without a previous history of infarction. Over the period of the study, ACA titres in the myocardial infarct group did not change significantly from those recorded on admission, nor did those patients with raised ACA titres have a higher prevalence of complications in hospital or in the early period after discharge.

Conclusions-There is no evidence that patients with an acute or previous myocardial infarct have higher ACA titres than those found in patients with ischaemic heart disease. Raised ACA titres soon after myocardial infarction do not influence immediate patient outcome.
\end{abstract}

\section{(F Clin Pathol 1993;46:1113-1115)}

The association between antibodies to cardiolipin and rare syndromes of venous and arterial thrombosis, recurrent fetal loss, and thrombocytopenia has been extensively reported. ${ }^{1-2}$ Recent work has also suggested a complex relation between anticardiolipin antibodies and coronary artery disease. ${ }^{3-7}$ In particular, raised titres of anticardiolipin antibodies in young survivors of myocardial infarction were found to be a marker of recurrent cardiovascular events. ${ }^{8}$ In the case of myocardial infarction it is not clear whether the antibody is present before infarction, initiated by myocardial ischaemia, ${ }^{9}$ or develops afterwards in response to muscle necrosis. ${ }^{10}$

Methods

The study group consisted of 111 patients, 83 men $(74 \cdot 8 \%)$ and 28 women $(25 \cdot 2 \%)$, aged between 31 and 88 years. They had been admitted to the coronary care unit with a suspected myocardial infarction. Myocardial infarction was diagnosed when at least two of the following criteria were met:chest pain for more than 30 minutes; characteristic electrocardiographic changes; and serial cardiac enzyme pattern typical of myocardial infarction. Patients with a history of connective tissue disease, other autoimmune disorders, or insulin dependent diabetes mellitus were excluded from the study. Myocardial infarction was confirmed in 83 of these patients (myocardial infarction group) (median age 61 years:range $31-88$ years), while the remaining 28 were diagnosed as having either ischaemic heart disease $(n=26)$ or unstable angina $(n=$ 2) (non-infarct group) (median age 63.5 years:range 38-78 years). Thrombolytic treatment was given to patients with a clinical diagnosis of myocardial infarction unless specific contraindications ${ }^{11}$ were present. Eleven patients died during the trial, nine of these while in hospital: all 11 were in the myocardial infarction group.

Blood samples for anticardiolipin antibody analysis were taken on admission, 24 hours later, and between five and seven days after admission. A fourth sample was taken six to eight weeks after admission at the outpatient follow up visit. Complete data were available on 98 patients, the omissions being due to death or absenteeism from outpatient clinics.

Antibodies to cardiolipin were analysed using a standard enzyme linked immunosorbent assay (ELISA) technique. ${ }^{12}$ All results were calculated using the same standard sera. The reference range was $0-10$ units for IgG anticardiolipin and 0-5 units for IgM anticardiolipin. All samples from the same patient were tested in parallel on the same ELISA plate to minimise plate to plate and day to day variations of results.

All data were stored in a database on a Prime 9955 minicomputer and analysed using the SPSSX statistical package. Group frequency distributions were compared using either the Mann-Whitney U-test, the $\chi^{2}$ test, or Fisher's exact test. Comparisons of serial IgG and IgM anticardiolipin antibody data were carried out using the Wilcoxon matched pairs signed ranks test.

\section{Results}

Patients were classified according to their anticardiolipin antibody response over the period during which they were able to give 
Patient details categorised by anticardiolipin antibody $(A L A)$ response

\begin{tabular}{|c|c|c|c|}
\hline \multirow[b]{2}{*}{ Demographic details } & \multicolumn{2}{|l|}{$A C A$ response } & \multirow[b]{2}{*}{$p$ Value } \\
\hline & $\begin{array}{l}\text { Negative } \\
(n=91)\end{array}$ & $\begin{array}{l}\text { Positive } \\
(n=20)\end{array}$ & \\
\hline \multirow{2}{*}{$\begin{array}{l}\text { Male } \\
\text { Female } \\
\text { Age (years): Median } \\
\text { (range) } \\
\text { Pre-admission history } \\
\quad \text { Angina } \\
\text { Hypertension } \\
\text { Previous MI }\end{array}$} & $\begin{array}{l}71(78 \cdot 0 \%) \\
20(22 \cdot 0 \%) \\
61 \cdot 0 \\
(36-88)\end{array}$ & $\begin{array}{l}12(60 \cdot 0 \%) \\
8(40 \cdot 0 \%) \\
69 \cdot 5 \\
(46-87)\end{array}$ & $\begin{array}{l}\mathrm{N} / \mathrm{S} \\
\mathrm{p}=0.0001\end{array}$ \\
\hline & $\begin{array}{l}39(42 \cdot 9 \%) \\
22(24 \cdot 2 \%) \\
22(24 \cdot 2 \%)\end{array}$ & $\begin{array}{r}12(60.0 \%) \\
8(40.0 \%) \\
7(35.0 \%)\end{array}$ & $\begin{array}{l}\text { N/S } \\
\text { N/S } \\
\text { N/S }\end{array}$ \\
\hline Thrombolytics given & $64(70 \cdot 3 \%)$ & $12(60 \cdot 0 \%)$ & $\mathrm{N} / \mathrm{S}$ \\
\hline $\begin{array}{l}\text { Inpatient complications } \\
\text { Heart failure } \\
\text { Cardiogenic shock } \\
\text { Pericarditis } \\
\text { Re-infarction } \\
\text { Death }\end{array}$ & $\begin{array}{c}(\mathrm{n}=22) \\
17(18 \cdot 7 \%) \\
4(4 \cdot 4 \%) \\
1(1 \cdot 1 \%) \\
3(3 \cdot 3 \%) \\
7(7 \cdot 7 \%)\end{array}$ & $\begin{array}{l}(\mathrm{n}=5) \\
3(15 \cdot 0 \%) \\
2(10 \cdot 0 \%)\end{array}$ & N/S \\
\hline $\begin{array}{l}\text { Post discharge complications } \\
\text { Angina } \\
\text { Breathlessness } \\
\text { Dressler's syndrome } \\
\text { Re-infarct } \\
\text { Death }\end{array}$ & $\begin{array}{c}(\mathrm{n}=45) \\
30(33 \cdot 0 \%) \\
29(31 \cdot 9 \%) \\
0(0 \cdot 0 \%) \\
1(1 \cdot 1 \%) \\
1(1 \cdot 1 \%)\end{array}$ & $\begin{array}{l}(\mathrm{n}=11) \\
6(30 \cdot 0 \%) \\
8(40 \cdot 0 \%) \\
0(0 \cdot 0 \%) \\
1(5 \cdot 0 \%) \\
1(5 \cdot 0 \%)\end{array}$ & $\mathbf{N} / \mathbf{S}$ \\
\hline \multicolumn{4}{|l|}{ Infarct history } \\
\hline \multirow{2}{*}{ Previous MI $\left\{\begin{array}{l}\text { Yes } \\
\text { No }\end{array}\right.$} & $22(24 \cdot 2 \%)$ & $7(35 \cdot 0 \%)$ & \\
\hline & $69(75 \cdot 8 \%)$ & $13(65 \cdot 0 \%)$ & \\
\hline $\begin{array}{l}\text { Previous or recent MI } \\
\text { No history of MI }\end{array}$ & $\begin{array}{c}82(90 \cdot 1 \%) \\
9(9 \cdot 9 \%)\end{array}$ & $\begin{array}{r}17(85 \cdot 0 \%) \\
3(15 \cdot 0 \%)\end{array}$ & \\
\hline Peak creatine kinase activity & $\begin{array}{l}734 \\
(42-4490)\end{array}$ & $\begin{array}{l}628 \\
(82-5610)\end{array}$ & $\mathrm{N} / \mathrm{S}$ \\
\hline
\end{tabular}

$\mathrm{MI}=$ Myocardial infarction
There was no significant difference in the anticardiolipin antibody titres of patients with previous or current myocardial infarction and those with no history of myocardial infarction; nor, at the time of admission, were the anticardiolipin antibody titres of those patients who had had a previous infarction significantly higher than those patients who had not.

Irrespective of anticardiolipin antibody response, the inpatient and post discharge complications occurred in equal proportions within the two groups (table). No cases of Dressler's syndrome occurred in the cohort during the period of follow up. The prevalence of complications, even in those patients with a recent myocardial infarction, was not significantly altered by the presence of raised anticardiolipin antibody titres. Clearly, the anticardiolipin antibody titres of these patients were not influenced by the occurrence of recent or earlier myocardial infarcts.

\section{Discussion}

The evolution of anticardiolipin antibodies in patients with ischaemic heart disease and myocardial infarction has been studied by serial measurements of anticardiolipin antibodies from the time of admission. Anticardiolipin antibody titres at admission serve not only as a baseline measurement against which all future values can be compared, but also allow the prevalence of anticardiolipin antibodies in survivors of previous myocardial infarction to be determined. The data show that some patients with angina pectoris and myocardial infarction have raised titres of anticardiolipin antibodies, but there is no significant difference in either the titre of anticardiolipin antibody or the proportion of patients with raised values in either group. Both myocardial necrosis ${ }^{10}$ and ischaemia ${ }^{9}$ may stimulate an immunological response, but we agree with De Catrina et $a l^{5}$ and Sletres $e t a l^{7}$ that there is no evidence to support the view that patients with a previous myocardial infarction are predisposed to higher titres of anticardiolipin antibodies compared with those with no previous infarct ${ }^{5}$; nor that the presence of anticardiolipin antibodies in survivors of myocardial infarction is a risk factor for subsequent coronary events. ${ }^{7}$

No significant correlation could be found between peak creatine kinase and mean anticardiolipin antibody titres. In both groups of patients no increase in anticardiolipin antibody titres could be detected over the period of the trial. There does not seem to be a correlation between the titre of anticardiolipin antibody and extent of myocardial necrosis.

Patients with raised anticardiolipin antibody titres did not have more complications either in hospital or immediately after discharge. This conflicts with the conclusions of Hamsten et $a{ }^{8}{ }^{8}$ who showed a significant correlation between consistently raised titres of anticardiolipin antibodies and cardiovascular complications in young survivors of myocar-
Patients with raised anticardiolipin antibody titres were older than those with normal values (mean differences 8.5 years; $95 \%$ confidence interval 4.1 to 12.9 years; $p=0.0001$ ) but did not have more complications (table). 
dial infarction. Because our study was carried out with an older coronary artery disease population, however, only five of whom were 45 years or younger (median age 61 years), and was designed to assess the short term evolution and influence of antibodies, direct comparison of results is not possible.

Our data show that raised anticardiolipin antibody titres occur in equal proportions in patients diagnosed as having either ischaemic heart disease or myocardial infarction. The occurrence of an acute or previous myocardial infarction does not raise anticardiolipin antibody titres above those found in ischaemic heart disease. Raised anticardiolipin antibody titres did not influence immediate patient outcome in terms of the occurrence of clinical complications. The long term outcome and clinical value of consistently raised titres of anticardiolipin antibodies is difficult to evaluate and requires further prospective study.

We thank the nursing staff of the coronary care unit and department of thoracic medicine for their help and assistance department of thoracic medicine
1 Harris EN, Gharavi AE, Hughes GRV. Antiphospholipid antibodies Clin Rheum Dis 1985;11:591-609.

2 Hughes GRV, Harris EN, Gharavi AE. The anticardiHughes GRV, Harris EN, Gharavi AE. The
olipin syndrome. $₹$ Rheumatol 1986;13:486-9.

3 Norberg R, Ernerudh J, Hamsten A, Unander AM, Årfors L. Phospholipid antibodies in cardiovascular disease. Acta Med Scand 1987;715(Suppl):93-8.

4 Mattila K, Vaarala O, Palosuo T, et al. Serologic response against cardiolipin and enterobacterial common antigen in young patients with acute myocardial infarction. Clin Immunol Immunopathol 1989;51:414-8.

5 De Caterina R, d'Ascanio A, Mazzone A, et al. Prevalence of anticardiolipin antibodies in coronary artery disease. Am $\mathcal{F}$ Cardiol 1990;65:922-3.

6 Kaplan SD, Chartash EK, Pizzarello RA, Furie RA. Cardiac manifestations of the antiphospholipid syn-

7 Sletres KE, Smith P, Abdelnoor M, Arnesen H, Wisloff F. Antiphospholipid antibodies after myocardial infarction and their relation to mortality, reinfarction and nonhaemorrhagic stroke. Lancet 1992;339:451-3.

8 Hamsten A, Björkholm M, Norberg R, de Faire U, Holm G. Antibodies to cardiolipin in young survivors of myocardial infarction: An association with recurrent cardiovascular events. Lancet 1986;1:113-6.

9 Klemp P, Cooper RC, Strauss FJ, Jordaans ER, Przybojewski JZ, Nel N. Anticardiolipin antibodies in ischaemic heart disease. Clin Exp Immunol 1988; 74:254-7.

10 Morton KE, Gavaghan TP, Krilis ST, et al. Coronary artery bypass graft failure-An autoimmune phenomenon? Lancet 1986;11:1353-6.

11 Spann JF Jr, Sherry S, Rubin RN. Techniques of achieving pulmonary, peripheral, and coronary thrombolysis. In: Hurst JW, ed. The heart. 6th edn. New York, McGraw-Hill, 1986:1916-22.

12 Harris EN, Gharavi AE, Patel SP, Hughes GRV. Evaluation of the anti-cardiolipin antibody test:report of an international workshop held 4 April 1986. Clin Exp Immunol 1987;68:215-22. 